Special Issue of the 6th International Congress \& Exhibition (APMAS2016), Maslak, Istanbul, Turkey, June 1-3, 2016

\title{
Enhanced Mechanical Performance of Aluminum Glass Fiber Reinforced Foam Material by $\mathrm{Cu}$ Modification
}

\author{
A.T. ERTÜRK ${ }^{a *}$ AND I. AYDIN ${ }^{b}$ \\ ${ }^{a}$ Kocaeli University, Ford Otosan Ihsaniye Vocational School of Automotive, Turkey \\ ${ }^{b}$ Kocaeli University, Department of Mechanical Engineering, Turkey
}

\begin{abstract}
Glass fiber-reinforced aluminum foam and its modified forms, using 1 and 3 wt.\% of $\mathrm{Cu}$, were produced by powder sintering process, using spherical carbamide particles as space holders. The foams with 40 and 60 vol.\% porosity fractions were successfully produced after water leaching and sintering procedures. Compression test was performed on foam samples to compare both, the compressive properties and energy absorption behavior of them. The composite foam samples with $\mathrm{Cu}$ modification have shown a higher compressive strength than the parent material foam. The average plateau stress and energy absorption capacity of foams produced in this study, achieved via utilizing $3 \mathrm{wt} . \% \mathrm{Cu}$, were $7.06 \mathrm{MPa}$ and $3.51 \mathrm{MJ} / \mathrm{m}^{3}$, respectively.
\end{abstract}

DOI: 10.12693/APhysPolA.131.470

PACS/topics: 81.05.Bx, 81.05.Rm, 81.20.Ev, 81.70.Bt

\section{Introduction}

Metallic foams are a type of cellular materials which combine struts in a complex positioning pattern. Their low density, high strength, and stiffness characteristics make these metallic materials to satisfy the strict requirement of such modern industry fields as automotive, railway, aerospace, biomedical industries, as well as in different segments of other engineering industries [1-3].

There are three basic routes of manufacturing metallic foams: powder metallurgical as a solid, casting as a liquid, and metallic vapor deposition as a gas state processing. The widespread commercial use of metallic foams requires improved characteristics and low production costs. Therefore, many research studies have attempted to enhance their mechanical properties efficiently and inexpensively. Recently significant research efforts of composite, hybrid and reinforced $[4,5]$ metal foams have been reported, aimed to improve their characteristics.

Cao et al. [6] have used an approach in which aluminum closed cell foam was fabricated by the melt route using copper-coated carbon fibers as a stabilizing component. They have concluded that carbon fibers enclosed in a liquid film function as networking and support force bearing agents.

A copper coating aluminum open-cell foam was studied for enhancing thermal and mechanical properties by Antenucci et al. [7]. They have reported that energy deformation behavior of the foam specimens was proportional to density. However, exceeding a specific density has caused a decrease of energy absorption and stress-strain curves have tended to uniform themselves.

Devivier et al. [8] have focused on optimization and improvement of mechanical properties of open cell

*corresponding author; e-mail: tamererturk@gmail.com aluminum foams using electro-deposited coatings of nickel. Results of applied compression tests have shown that mechanical properties regarding the energy absorption capacity were directly proportional to the density or deposition time.

Another effort on improving mechanical properties was implemented by Sun et al. [9], in which $\mathrm{Al} / \mathrm{Cu}$ hybrid open-cell aluminum foams were subjected to an annealing process. Authors have reported that a favorable condition of annealing significantly enhances the energy absorption capacity by increasing the coating material ductility.

The compressive behavior of closed-cell copper-coated carbon fiber/aluminum composite foam was assessed under quasi-static and high strain rate loading conditions for investigating the failure modes of fibers in the matrix by Mu et al. [10]. The improvement of damping capacity is connected with the contribution of increasing interfacial micro slip and micro-plasticity deformation which is based on micro cracks in aluminum foam in the fiber aluminum interface [11].

An effort to stabilize metal films of copper-coated carbon fiber/aluminum composite foam was performed by Mu et al. [12]. Authors have reported that fibers in an $\mathrm{Al}$ foam play an active role in its stabilization by preventing cell wall rupture and reducing coalescence, when fabricated by the melt route.

Among several different ways, using space holder is one of the cheapest methods. In the present study, aluminum open cell glass fiber reinforced foam (GFRF) material has been produced by copper modification to improve the mechanical properties, using space holder method. The microstructure and mechanical properties of the produced foams have been studied regarding compressive properties and energy absorption behavior. Stiffness features have been improved with the help of addition of aluminum-copper intermetallic to aluminum-based foam. 


\section{Materials and equipment}

Gas-atomized aluminum powder with particle size in the range of 30-50 $\mu \mathrm{m}$, with particles of irregular shape was supplied by Gurel Makina Inc. Chemical composition of the aluminum powder sample is (wt.\%) $95.7 \mathrm{Al}$, $3.26 \mathrm{Si}, 0.41 \mathrm{Fe}, 0.21 \mathrm{Mg}, 0.02 \mathrm{Mn}, 0.12 \mathrm{Ti}$ and $0.09 \mathrm{Cu}$. Spherically-shaped carbamide $\left(\mathrm{CH}_{4} \mathrm{~N}_{2} \mathrm{O}\right)$ particles, reduced by a series of sieves to $1-2 \mathrm{~mm}$ size, were used as a space-holder material. The carbamide has a density of $1.32 \mathrm{~g} \mathrm{~cm}^{-3}$, melting temperature of $133^{\circ} \mathrm{C}$, and solubility in ethanol (at $20^{\circ} \mathrm{C}$ ) equal to $50 \mathrm{~g} / \mathrm{l}$. Glass-fiber (E-glass) was used in the mixing stage of production, as the reinforcement. The diameter of the fiber was 15$20 \mu \mathrm{m}$, the length was $6 \mathrm{~mm}$ and the density was about $2.45 \mathrm{~g} \mathrm{~cm}^{-3}$ (see Fig. 1a).

The percentage of glass fiber in prepared composites was 1 and 3 wt.\%. The weight ratios of the aluminum powder, carbamide and glass fibers (1, 3 wt.\%) were calculated to obtain defined porosities in sintered compact. A small amount of ethanol was sprayed. The mixture was compacted in a die $(d=22 \mathrm{~mm}, h=20 \mathrm{~mm})$ under pressure of $325 \mathrm{MPa}$.

Space-holder in the green compact was removed in water at $80^{\circ} \mathrm{C}$ and weighed at regular intervals to determine the leaching proportion and then dehydrated in a vacuum furnace $\left(P=10^{-4} \mathrm{~Pa}\right)$ at $50^{\circ} \mathrm{C}$ for $2 \mathrm{~h}$. Total time of removing the carbamide from foams was approximately $135 \mathrm{~min}$. After the removal stage, the compacts were sintered in liquid-state (at $650{ }^{\circ} \mathrm{C}$ ) in a vacuum furnace $(P=-750 \mathrm{~mm} \mathrm{Hg})$ for $3 \mathrm{~h}$. The compacts were cooled in the furnace after sintering. The details of foam production stages can be found in a previous study, in Ref. 3. The macro- and micro-structure of the foams were examined using Nikon SMZ-745T trinocular model stereo microscope and FEI Quanta 50 SEM/EDS equipment. Compression tests were performed using DARTEC universal tensile testing equipment at a constant deformation rate of $1 \mathrm{~mm} \mathrm{~min}^{-1}$. The deposition process parameters of magnetron sputtering are given in Table I.

TABLE I

Magnetron sputtering parameters.

\begin{tabular}{c|c}
\hline \hline Parameter & Value \\
\hline Vacuum & $3 \times 10^{-3} \mathrm{~Pa}$ \\
DC power & $120 \mathrm{~W}$ \\
Each sputtering time & $2 \mathrm{~min}$ \\
Argon pressure & $0.6 \mathrm{~Pa}$
\end{tabular}

\section{Results and discussion}

The Cu-coated glass fiber thickness after magnetron sputtering was approximately $50 \mu \mathrm{m}$, which was larger than that of the original glass fiber $(\sim 15 \mu \mathrm{m})$, as shown in Fig. 1a and b. Glass fibers were uniformly coated with $\mathrm{Cu}$ films consecutively six times using a Bal-Tec
SCD 005 DC-magnetron sputtering device (see Fig. 1d). Raw materials were mixed together, as shown in Fig. 1c.

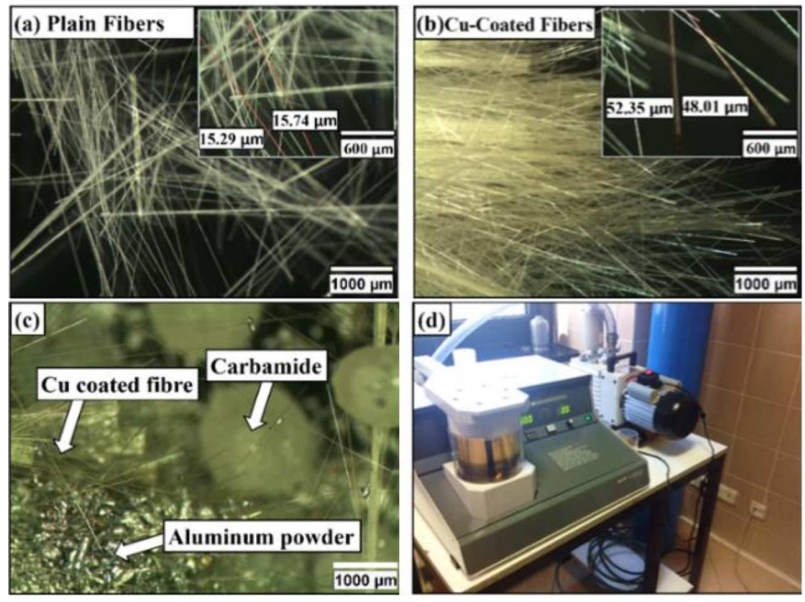

Fig. 1. Materials and coating machine (a) plain fibers, (b) Cu-coated fibers, (c) blending, (d) sputter coating machine.
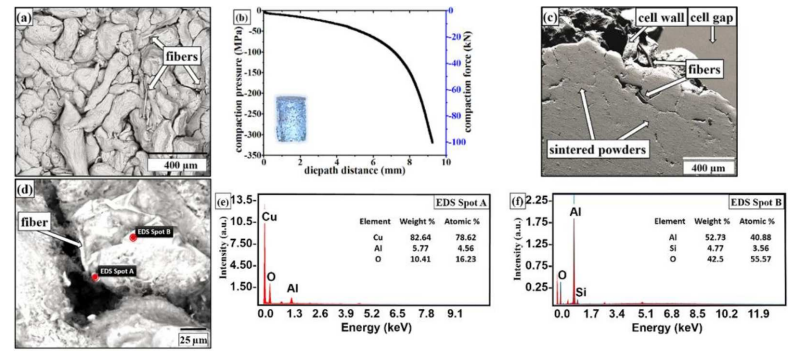

Fig. 2. Structural analysis (a) powder compaction, (b) pressing condition, (c) after sintering, (d) SEM-EDS analysis, (e) EDS spectrum of spot A, (f) EDS spectrum of spot B.

Fiber distribution in produced foams was fairly uniform. Figure 2a shows the forms obtained at $325 \mathrm{MPa}$ pressure. It is seen that after pressing the shape of the powders have changed and some of the fibers have broken. Limit deformation value of carbamide was examined in the previous study [3]. The determined compaction conditions were applied at a rate of $0.5 \mathrm{~mm} \mathrm{~min}^{-1}$. Figure $2 \mathrm{~b}$ presents pressure/force values versus die-path distance. The physical dimensions of carbamide particles are maintained after the compaction. A homogeneous and uniform structure was obtained. Formation of a solid mass at cell wall was observed typically after sintering process, as seen in Fig. 2c. The boundaries of the powder particles contain several pores. The presence of fiber has been the source of the pores due to their wetting properties. As a solution to the wettability problem in the reinforced metal foams, application of a suitable copper coating on the glass fiber is used. It was observed that the fibers have mostly stuck to the cell wall, which can have a preventive role against cell wall rupture. Compression test 
results have confirmed this theory, when coated fibers were used (Table II). Another causal agent for strength improvement is aluminum hardening with the addition of copper solid-solution.

TABLE II

Structure and mechanical behavior of the produced foams with $\mathrm{Cu}$-coated fibers.

\begin{tabular}{|c|c|c|c|c|c|c|}
\hline \multirow[b]{2}{*}{ Foam sample } & \multirow{2}{*}{$\begin{array}{c}\text { Relative } \\
\text { density } \\
{\left[\rho_{\mathrm{f}} / \rho_{\mathrm{Al}}\right]}\end{array}$} & \multirow[b]{2}{*}{$\begin{array}{c}\text { Porosity } \\
{[\%]}\end{array}$} & \multicolumn{2}{|c|}{ Spherical diameter $[\mu \mathrm{m}]$} & \multirow{2}{*}{$\begin{array}{c}\text { Average } \\
\text { plateau } \\
\text { stress [MPa] }\end{array}$} & \multirow{2}{*}{$\begin{array}{c}\text { Energy } \\
\text { absorption } \\
{\left[\mathrm{MJ} \mathrm{m}^{-3}\right]}\end{array}$} \\
\hline & & & Mean & $\begin{array}{l}\text { Standard } \\
\text { deviation }\end{array}$ & & \\
\hline Al-60 Carb-3 wt.\% Cu/GF & 0.4173 & 59.78 & 1163.5 & 102.7 & 6.37 & 3.13 \\
\hline Al-60 Carb-1 wt. $\%$ Cu/GF & 0.4016 & 59.82 & 1276.2 & 117.5 & 5.30 & 2.74 \\
\hline Al-40 Carb-3 wt. $\%$ Cu/GF & 0.6177 & 40.02 & 1049.4 & 104.1 & 7.06 & 3.51 \\
\hline Al-40 Carb-1 wt. $\% \mathrm{Cu} / \mathrm{GF}$ & 0.6105 & 39.69 & 1218.1 & 123.4 & 5.01 & 2.46 \\
\hline Al-60 Carb & 0.3957 & 61.18 & 1045.2 & 107.1 & 4.20 & 2.12 \\
\hline Al-40 Carb & 0.5912 & 41.55 & 1147.7 & 126.3 & 4.71 & 2.29 \\
\hline
\end{tabular}

SEM-EDS elemental analysis in the spots indexed as $\mathrm{A}$ and $\mathrm{B}$, reveals that intermetallic and oxide layer have formed during the sintering stage (Fig. 2d-f). Interfacial contact between aluminum matrix and copper coating can cause various metallurgic diffusion mechanisms in the interface layer, such as Kirkendall effect, precipitation formation, intermetallic growth and stress aging. After sintering, the phases are probably in the form of mostly observed intermetallics, such as $\mathrm{CuAl}_{2}, \mathrm{AlCu}$, and $\mathrm{Al}_{4} \mathrm{Cu}_{9}$ and are formed around coated fiber and aluminum matrix interface, due to their interaction. The intermetallic phases, which have occurred during sintering stage, play the role of binding agent in the composite foam system.

The performance of coating, regarding mechanical properties, was evaluated by means of stress-strain data from Table II. The 3 wt.\% Cu-modified-fiber/aluminum foam exhibits higher plastic collapse stress. Therefore, the GFRFs made with $\mathrm{Cu}$-coating give the best mechanical properties. The spherical diameter of the pores in foams was determined using Clemex Vision image analysis software and the results are given in Table II. After the sintering stage, the dimensions were measured for volume calculation, and the density of the green foam was calculated by dividing the mass by its volume.

Porosities of the foam materials were calculated using the following formula [3]:

$$
\text { porosity }=\left[1-\left(\frac{\rho_{f}}{\rho_{A l}}\right)\right] \times 100,
$$

where, $\rho_{f}$ and $\rho_{A l}$ are densities of foam and bulk aluminum (2.75 $\mathrm{g} \mathrm{cm}^{-3}$ for aluminum powder), respectively. Compression tests were conducted by quasi-static loading, in uniaxial conditions along the directions parallel to the compacting directions on foam samples with asobtained sizes, taking into account ASTM E9-09 standard. The energy absorption capacity of obtained foam was calculated from area under the compressive curve in the range of its plateau region [3]:

$$
W=\int_{0}^{\varepsilon} \sigma d \varepsilon
$$

The test results of the produced foams with $\mathrm{Cu}$ coated fibers are given in Table II. Similar results had been obtained previously in GFRFs [3]. The average plateau stress of the considered foams in the stroke range of 2 to $16 \mathrm{~mm}$ was found to be increasing for glass fibers coated with up to 3 wt.\% Cu. The values of energy absorption vary in the range from 2.12 to $3.51 \mathrm{MJ} \mathrm{m}^{-3}$.

As can be seen from Table II, after liquid state sintering at $650{ }^{\circ} \mathrm{C}$, foams reinforced with $\mathrm{Cu}$-coated glass fiber with the lowest porosity of 40 vol. $\%$ and 3 wt.\% glass fiber content, have shown the highest strength of $7.06 \mathrm{MPa}$. Also, the application of copper coating improves the compression and energy absorption properties of the GFRFs. Enhancement of mechanical performance indicates that strong interfacial bonds of aluminum/glass fiber have formed during the sintering stage. However, some of the sintered foam samples show brittle characteristics, with irregular compression curves, due to presence of micro porosity. Micro porosity can act as initial cracks. The results have shown that the compressive strength and energy absorption capacity rely on two parameters: sintering temperature and the fractions of glass fiber. Compression properties were increased by decreasing the carbamide fraction and increasing glass fiber fraction.

\section{Conclusions}

Effects of copper modification on the glass-fiberreinforced $\mathrm{Al}$-foams with different carbamide content on microstructure, compression and energy absorption properties were investigated. Based on the results, the following conclusions can be drawn. Poor wettability is one of the major problems during the fabrication of fiberreinforced aluminum foam materials. Copper-coating 
provides a solution to the problem of wettability. Beside this, it was noted that the formation of intermetallic compounds with the aluminum matrix improves mechanical properties.

\section{Acknowledgments}

The authors gratefully acknowledge the financial support rendered by The Scientific Research Projects Unit of Kocaeli University, Turkey (KOU-BAP, 2015/89).

\section{References}

[1] M.F. Ashby, A.G. Evans, N.A. Fleck, L.J. Gibson, J.W. Hutchinson, H.N.G. Wadley, Metal Foams: A Design Guide, Butterworth Heinemann, Woburn 2000.

[2] J. Banhart, Prog. Mater. Sci. 46, 559 (2001).

[3] A. T. Ertürk, Acta Phys. Pol. A 129, 592 (2016).
[4] M.R. Moradi, A. Moloodi, A. Habibolahzadeh, Procedia Mater. Sci. 11, 553 (2015).

[5] M. Garcia-Avila, M. Portanova, A. Rabiei, Compos. Struct. 125, 202 (2015).

[6] Z.K. Cao, B. Li, G.C. Yao, Y. Wang, Mater. Sci. Eng. A 486, 350 (2008).

[7] A. Antenucci, S. Guarino, V. Tagliaferri, N. Ucciardello, Mater. Des. 59, 124 (2014).

[8] C. Devivier, V. Tagliaferri, F. Trovalusci, N. Ucciardello, Mater. Des. 86, 272 (2015).

[9] Y. Sun, R. Burgueno, W. Wang, I. Lee, Mater. Sci. Eng. A 613, 340 (2014).

[10] Y. Mu, G. Yao, Z. Cao, H. Luo, G. Zu, Scr. Mater. 64, 61 (2011)

[11] Y. Mu, G. Yao, G. Zu, Z. Cao, Mater. Des. 31, 4423 (2010).

[12] Y. Mu, G. Zu, Z. Cao, G. Yao, Q. Wang, Scr. Mater. 68, 459 (2013). 